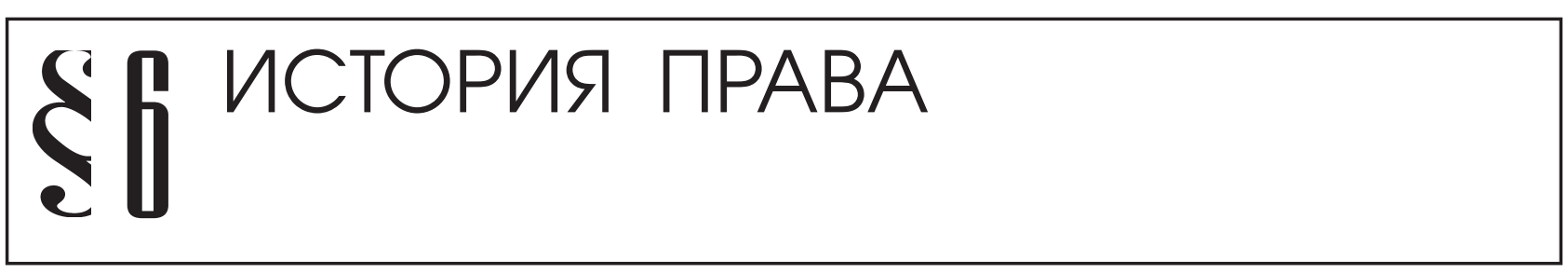

Георгиевский Э.В.

\title{
К ВОПРОСУ ОБ ОБЩЕСТВЕННО-ПОЛИТИЧЕСКИХ И КУЛЬТУРНО-РЕЛИГИОЗНЫХ ОСНОВАНИЯХ ДРЕВНЕГЕРМАНСКОГО УГОЛОВНО-ПРАВОВОГО ГЕНЕЗИСА
}

Аннотация: Предметом исследования является исторический процесс уголовно-правового генезиса у древнегерманских племен, в период, предтествовавший образованию первых варварских королевств эпохи меровингов. Основаниями такого правогенеза является совокупность общественно-политических и культурно-религиозных признаков, отражсающих полукочевой образ жизни и быта древних германщев, их воинственность, любовь к свободе, и праву силь. Особенности устройства общинной организации и мифо-поэтического отражения окружающего мира, соединенные в одно иелое, привели к формированию совершенно особого правового восприятия древних германцев времен Цезаря и Тацита галло-римским окружением. В работе используется конкретно-исторический метод исследования, опирающийся на анализ и научную интерпретацию историко-правового материала. Появление на исторической сиене древних германских племен связано с процессом их переселения, движения, смень «ареала» существования, а значит, неизбежно с военными столкновениями с коренным населением захватываемых земель. Отсюда рождение права силь, формирующего особый образ человека-воина, промедшего процедуру инициаии, свободного юридического субъекта. Пленный враг, чужой, а значит не только враг, но и преступник, достойный самого сурового наказания, за то, что оказал сопротивление. Право силы, право войны санкиионируется верховныли антропоморфныли божествами, а значит близкими и понятными, достойными подражсания или порицания. Враг-герой иногда достоин уважения. Свобода юридического субъекта выражается в возможности всеобъемлющего участия в жизни общества, в решении вопросов войны и мира, правосудия. И хотя правовая сторона жизни общества не выделяется в особую сферу, она инвариантна, и, вместе с тем, проста и понятна каждому. Правовой обычай в основном сформирован сочиально-политическим устройством древнегерманского общества, но также неразрывно связан с религией, которая также подвержена видовой трансформаиии. Во многом, характер правогенеза у древних германцев носил уголовно-правовой оттенок, так как неразрывно был связан с решением именно тех важнейших вопросов (жизни, смерти, чести, родового кровомщения), которые изначально во всем мире относились именно к данной сфере правового регулирования.

Review: The subject under review is the historical process of the genesis of criminal law in Ancient German tribes prior to the formation of the first Barbarian kingdoms of the Merovingian epoch. The grounds for that genesis of law were the combination of socio-political and cultural-religious features of the seminomadic style of life and everyday life of Ancient Germans, their hostility, love for freedom and 'the rule of force'. Peculiarities of community-based organizations and poetical mythopoetic reflection of the surrounding world, combined as one whole, led to the formation of a completely different legal perception of Germans of the times of Caesar and Tacitus. The researcher uses the particular historical research method which is based on the analysis and scientific interpretation of historical and legal materials. Appearance of Ancient German tribes on the historical scene was caused by their migration and change of the territory which, in its turn, inevitably led to military collusions with the native population of conquered lands. This is where the rule of force comes from. The rule of force creates a special image of a warrior who underwent the initiation procedure and became a free legal entity. A captured enemy is an alien and not only an enemy but also a criminal who deserves the most severe punishment for showing resistance. The 'rule of force' and the 'right of war' are sanctioned by the supreme anthropomorphic gods who are close and understandable and therefore worthy of respect or blame. However, a heroic enemy sometimes can be worthy of respect too. The free- 


\section{Политика и общество 5 (113) • 2014}

dom of a legal entity is expressed in his right to fully participate in public life and decision making process regarding war and peace and justice. Even though the legal side of public life was not viewed as an individual sphere, it was invariant and at the same time simple and easy to understand for everyone. Legal customs were mostly formed by the social and political structure of the Ancient German society and at the same time they were inextricably entwined with religion which was susceptible to transformation, too. In many ways, the nature of the law genesis of Ancient Germans had a criminal law aspect because it was inseparably related to the solution of the most important issues (death, life, honor and blood feud) which had been initially referred to that sphere of legal regulation all over the world.

Ключевые слова: правогенез, Древняя Германия, война, пленный, жертва, галль, религия, мифология, оппозиция, христианство.

Keywords: law genesis, Ancient Germany, war, captive (prisoner), victim, Gauls, religion, mythology, opposition, Christianity.

$\Pi$ равогенез любого народа (общества) формируется в русле, практически, одних и тех же социальных и культурных закономерностей, составляющих его основу. Более того, «правогенез - это не просто сторона, а решающий фактор становления общества» ${ }^{1}$. Не являлась категорическим исключением в этом плане и Древняя Германия в эпоху, предшествовавшую формированию первых варварских королевств.

Одно из первых исторических упоминаний о Древней Германии встречается в произведении «Об океане» путешественника из Массалии (греческая колония на месте современного Марселя) Пифея (Питеаса) около 325 г. до н. э. ${ }^{2}$ На территории Германии многочисленные племена появились в VI - I вв. до н. э. Эти племена были очень близки между собой по языку, духовной и материальной культуре. Практически все эти племена пришли из Южной Скандинавии, Ютландии, с побережий Балтийского и Северного морей³.

Гай Юлий Цезарь в своих Записках о войне с галлами сообщает, что в 109 г. до н. э. кимбры, первые из германцев, ворвались в Галлию 4 . После окончания войны с гельветами в земли секванов в Галлии вторгся германский царь Ариовист, прославившийся свой жестокостью и вздорностью характера. Одним из способов правления Ариовиста в отношении покоренных племен был институт заложничества. Ариовист требовал в заложники детей самых знатных граждан и подвергал их чудовищным наказаниям, если что-либо происходило не так, как было им

${ }^{1}$ См.: Шалютин Б.С. Правогенез как фактор становления общества и человека // Вопросы философии. 2011. № 11. С. 18.

${ }^{2}$ См.: История средних веков. Т. 1. М., 1941. С. 30.

3 См.: Ковалев И.В. Очерки истории Германии с древнейших времен до 1918 г. М., 1959. С. 7.

${ }^{4}$ Цезарь Гай Юлий Записки о войне с галлами. Книга 1. М., 1946. С. 19. установлено 5 . Интересным представляется наблюдение Б.С. Шалютина, отмечающего, что женщины, находящиеся в другом роде в качестве заложниц, в том числе, открывали, тем самым, своеобразный канал принуждающего воздействия на волю противостоящего рода. В то же время, взаимное заложничество являлось надежным фактором «блокировки и прекращения конфликтов между родами» ${ }^{6}$.

По предположению Корнелия Тацита, термин «германцы» впервые был применен галлами по отношению к представителям племени тунгров, которые одними из первых переправились через Рейн и потеснили галлов. Впоследствии этот термин стал применяться по отношению и к другим зарейнским племенам ${ }^{7}$. А.Д. Удальцов авторитетно утверждает, что термин «германцы» употребили кельты ${ }^{8}$ в отношении группы племен, проживавших в бассейне рек Везера, нижней и средней Эльбы, а также в юго-восточной части Скандинавского полуострова и на полуострове Ютландия9. Согласно точке зрения Е.П. Глушанина, термин германцы (от латинского «germani» - подлинный), римляне применяли по отношению к той части галлов, которые отличались большей дикостью, имели более светлый цвет волос, желая, тем самым, подчеркнуть истинность их природного происхождения ${ }^{10}$.

\footnotetext{
${ }^{5}$ См.: Записки Юлия Цезаря и его продолжателей о галльской войне, о гражданской войне об александрийской войне, об африканской войне. М. - Л., 1948. С. 23 - 24.

${ }^{6}$ См.: Шалютин Б.С. Правогенез как фактор становления общества и человека. С. 17.

${ }^{7}$ Тацит Корнелий Сочинения в 2 т. Т. 1: Анналы. Малые произведения. Ленинград, 1969. С. 354.

${ }^{8}$ Кельты исторически предшествовали германским племенам.

${ }^{9}$ См.: История средних веков. Т. 1. С. $28-29$.

${ }^{10}$ История Германии: учебное пособие. В 3 т. / Под общ. ред. Б. Бонвеча, Ю.В. Галактионова. М., 2008. Т. 1: С древнейших времен до создания Германской империи. С. $20-21$.
} 
Древние германцы очень негативно относились к этническому смешению с другими племенами, что позволило им «сохранить изначальную чистоту и похожесть на самих себя» ${ }^{11}$. Жизнь их характеризуется достаточной простотой («на старый лад»). Особенно это касается тех территорий, которые значительно удалены от границ с галлами ${ }^{12}$. Однако в первые годы знакомства римского мира с германцами, сам термин «германцы» отражал не столько этнические особенности того или иного племени, сколько «восходящую к римлянам ученую и политическую конструкцию» ${ }^{13}$. Сегодня исследователи пришли к компромиссу, в соответствии с которым древний германский племенной мир можно разделить на три этногеографические группы германцев, выделившихся к середине I тысячелетия до н. э. из «индоевропейского субстрата». Это северная группа (Северная Германия, Ютландия и Южная Скандинавия); восточная группа (заэльбские территории вплоть до Вислы); западная группа (междуречье Рейна и Эльбы в среднем ее течении до верховьев Дуная) $)^{14}$.

О характере структуры древнегерманского общества конца прошлой и начала нынешней эры позволяют судить описания быта и общественного строя, осуществленные римскими и греческими исследователями. Так, например, упоминание Тацитом о замене, обязательной в кровнородственном обществе, кровной мести выкупом вполне может свидетельствовать о некоторых процессах перехода общины кровнородственной в общину соседскую. Фактически, о том же могут свидетельствовать данные Тацита, сообщающего о специфике поселения древних германцев и их тяге к постройке одиночных домов, достаточно далеко отстоящих от других ${ }^{15}$. О том, что, например, у салических франков

11 Хотя необходимо, очевидно, учитывать, что К. Тацит воспринимал древних германцев «одномоментно», то есть без связи с их предыдущим и последующим этническим развитием. Согласно мнению А.Д. Удальцова, население древней Германии представляло собой продукт смешения нескольких этнических и даже расовых типов (См.: История средних веков. Т. 1. С. 28).

${ }^{12}$ См.: Тащит Корнелий Сочинения в 2 т. Т. 1: Анналы. Малые произведения. С. 355.

${ }^{13}$ См.: История Германии: учебное пособие. В 3 т. С. 22.

14 Там же. С. 24.

15 Тацит Корнелий Сочинения в 2 т. Т. 1: Анналы. Малые произведения. С. 360 . до сельской общины существовала община родовая, которая сохранила в своих пережитках отношения еще более ранние, чем отношения матриархата, говорит Г.М. Данилова ${ }^{16}$.

Изучая специфику аграрных отношений у древних германцев времен Цезаря, Н.П. Грацианский высказывает предположение, что наиболее характерным термином, отражающим положение на земле древних германцев, является термин «полукочевничество». Они еще не осели окончательно на земле, но уже по очереди занимаются земледелием, чередуя эти занятия с войной. Они уже почти земледельцы, так как, минимум, по году или два работают на поле, но при этом умело сочетают эти занятия со скотоводством ${ }^{17}$. Каждое племя раздроблено на более мелкие «вполне самодавлеющие кровные соединения», со своими собственными начальниками и старейшинами. При этом, как считает Н.П. Грацианский, кровным подразделениям вполне могли соответствовать подразделения территориальные ${ }^{18}$. Д.М. Петрушевский отмечает, что такие особенности хозяйственных условий являются прямым следствием политики племенных предводителей древних германцев, которые в военно-политических целях не хотели, чтобы воин-германец превратился в земледельца ${ }^{19}$.

Согласно точке зрения Е.А. Сорокиной, сегодня среди исследователей достаточно спорным считается вопрос о существовании у древних германцев так называемой «домовой общины», предполагающей существование «длинных домов», в которых могло совместно жить и трудиться несколько десятков человек (вполне возможно, что и несколько поколений $)^{20}$. М.О. Косвен полагает, что у древних германцев времен Цезаря, во всяком случае, основной структурной единицей, характеризую-

\footnotetext{
${ }^{16}$ Данилова Г.М. Возникновение феодальных отношений у франков VI - VII вв. Петрозаводск, 1969. С. 72 - 73.

${ }^{17}$ Грацианский Н.П. Из социально-экономической истории западно-европейского средневековья. Сборник статей. М., 1960. С. $64-66$.

${ }^{18}$ Там же. С. 68.

19 Петрушевский Д.М. Очерки из истории средневекового общества и государства. М., 1922. С. 153.

${ }^{20}$ Сорокина Е.А. Статус семьи у древних германцев (к проблеме семантической реконструкции) // Индоевропейское языкознание и классическая филология. 2009. Т. ХІІІ. № 1. C. 484 .
} 


\section{Политика и общество 5 (113) • 2014}

щей общественное устройство, выступала патронимия. «Германская патронимия, - сообщает М.О. Косвен, - является одной из единиц землепользования и одновременно - военного построения. Патронимия имеет ряд правовых и обрядовых функций: она определяет круг дружественной и враждебной солидарности и круг получателей части уголовной пени, она участвует в торжественном акте вручения оружия совершеннолетнему, является участницей брачного обряда и свидетельницей наказания неверной жены. Принадлежность к большой патронимии составляет основание знатности и благоденствия» ${ }^{21}$.

Таким образом, М.О. Косвен резюмирует, что у древних германцев времен Цезаря существовало три родственные группы - род, патронимия и большая семья. Эти структурные единицы являлись основными не только в вопросах войны и мира, преступления и наказания, но и в вопросах землепользования и землевладения, в том числе. Е.А. Сорокина полагает, что кроме большой семьи у древних германцев существует также и малая семья как минимальная социальная ячейка, в которой совместно проживали только супруги и дети ${ }^{22}$. Г. Дельбрюк определяет древнегерманскую общину как «областное товарищество», так как по типу поселения она была деревней, по месту расселения - округом, по своим размерам - сотней, по своим внутренним связям - родом ${ }^{23}$.

Цари и вожди, хоть и выбираются из наиболее знатных и доблестных людей, но безграничной властью не обладают ${ }^{24}$. «Альдерманы, или хунни ${ }^{25}$, яв-

${ }^{21}$ Косвен М.О. Семейная община и патронимия. М., 1963. C. 130 .

${ }^{22}$ Сорокина Е.А. Указ. соч. С. 490.

${ }^{23}$ Дельбрюк Г. История военного искусства в рамках политической истории. Т. 2: Германцы. СПб., 1999. С. 11.

${ }^{24}$ П.С. Стефанович полагает, что отношения между германскими королями и дружинниками изначально были основаны не на идеальных представлениях о верности, а на взаимной материальной выгоде (Стефанович П.С. Дружинный строй в Древней Руси и у древних германцев: существовала ли клятва верности вождю (правителю)? // Древняя Русь. Вопросы медиевистики. 2008. № 2. С. 40).

${ }^{25} \mathrm{~K}$. Лампрехт утверждает, что терминология в обозначении общинных начальников имеет достаточно четкую историческую предопределенность. Термины «thunginus», «ealdor», «hunno» были прочно связаны с такими понятиями, как старый, достопочтенный (Лампрехт К. История германского народа. Т. 1. М., 1894. С. 105). ляются начальниками и руководителями общин во время мира и предводителями мужчин во время войны. Но они живут с народом и в народе. В социальном отношении они такие же свободные члены общины, как и все другие. Их авторитет не настолько высок, чтобы сохранить мир при крупных распрях или тяжелых преступлениях. Их положение не настолько высоко, а их кругозор не настолько широк, чтобы руководить политикой» ${ }^{26}$.

Вообще вопрос о легитимации королевской власти у древних германцев относится к числу достаточно спорных и сложных. Согласно точке зрения А.А. Турыгина, у древних германцев преобладала личная и родовая формы легитимации королевской власти. Именно могущество и самостоятельность отдельных родов, из которых происходили племенные правители, военачальники, а затем и племенные герцоги, позволяли со временем создавать их представителям крупные территориально-этнические образования, союз которых и составил основу германской государственности в эпоху раннего Средневековья ${ }^{27}$. Именно из их среды выбирались «князья», «первейшие», которые должны были ездить по округам, чтобы творить суд, принимать важные решения в области внешней и внутренней политики. Привлекались к таким обсуждениям также и хунни ${ }^{28}$.

Структурный состав древнегерманского общества с социально-политической точки зрения включал в себя военную племенную знать разных уровней, рядовых свободных германцев и рабов. Как считает М. Куторга, в древней догосударственной Германии именно состояние свободы или несвободы являлось основанием деления всего общества на два совершено отдельных сословия. Свободный - это не просто антипод лица несвободного, это полноправный член древнегерманского общества, которому обычаем предоставляется защита от внешнего неприятеля, возможность владения независимым, соединенным с особенными преимуществами, недвижимым имуществом, а также воз-

\footnotetext{
${ }^{26}$ См.: Дельбрюк Г. История военного искусства в рамках политической истории. С. 12.

27 Турыгин А.А. Формы легитимации королевской власти в средневековой германской истории // Вестник российского государственного гуманитарного университета. 2010. № 14. C. 94 .

${ }^{28}$ Дельбрюк Г. Указ. соч. С. 12.
} 
можность участия во всех общественных делах (заседаниях собраний, отправлении правосудия, принесения жертв $)^{29}$.

К III в. н. э. социальный состав ряда германских племен начинает меняться, уподобляясь римской структуре. Германский нобилитет начинает получать права римского гражданства, римского всадничества. С другой стороны, обезземелившиеся германцы превращались в колонов, обрабатывая поля своих знатных соплеменников ${ }^{30}$.

Особое влияние на формирование первых правовых опытов древних германцев оказывала их религия, уходящая корнями в общее индоевропейское прошлое. Многочисленные древние германские племена вели свои роды от порожденного Землей бога Туистона (Туиско), у которого был сын Манн непосредственный прародитель германского народа. А сыновья Манна дали жизнь многочисленным германским племенам, по именам которых эти племена начали именоваться ${ }^{31}$.

Часть древнегерманских богов Тацит называет именами римских и греческих богов. Это и Меркурий ${ }^{32}$, и Геркулес, и Марс ${ }^{33}$, и Изида ${ }^{34}$. Фактически же это только соответствующие им древнегерманские боги Донар, Водан, Тиу и др. ${ }^{35}$ Древнегерманские боги антропоморфны, они наделяются человеческими качествами ${ }^{36}$. Более того, они смертны, но они не могут находиться в стенах каких-либо храмов, и выносятся древними германцами в дубравы и рощи, которые становятся священными.

Северная (скандинавская) ветвь древнегерманских племен также имела целую плеяду богов, ока-

${ }^{29}$ Куторга М. Политическое устройство германцев до шестого столетия. СПб., 1837. С. $11-12$.

${ }^{30}$ См.: История Германии: учебное пособие. В 3 т. С. 39.

${ }^{31}$ См.: Тацит Корнелий Сочинения в 2 т. Т. 1: Анналы. Малые произведения. С. 354.

32 Адам Бременский сообщает о том, что древние саксы приносили Меркурию человеческие жертвы (Адам Бременский, Гельмольд из Босау, Арнольд Любекский Славянские хроники. М., 2011. С. 12).

33 О том, что Марсу приносились человеческие жертвы (умерщвлялись пленные) готами сообщает Иордан (Иордан О происхождении и деяниях гетов. М., 1960. С. 73).

${ }^{34}$ См.: Тациит Корнелий Сочинения в 2 т. Т. 1: Анналы. Малые произведения. С. 357.

35 См.: Введение в германскую филологию: Учебник для филологических факультетов. М., 2000. С. 13 - 14.

${ }^{36}$ Там же. С. 14. зывающих влияние на формирование правовой идеологии. Более того, именно норвежская и древнеисландская эпическая литература, являясь одними из самых богатейших и самых разнообразных средневековых европейских национальных литератур, сохранили и донесли до нас архаические жанры древнегерманской поэзии, которые практически исчезли у других древнегерманских народов, за исключением Англии ${ }^{37}$.

Одним из богов, имеющих непосредственное отношение к праву, был Тюр. Тюр был и предшественником и, одновременно, своеобразным соперником Одина (верховного бога, бога царей, мага). Этот бог не является дублером Одина, он не меняет облик, не капризничает, но именно он воздает воинам то, что им было положено за их отвагу. Воздаяние за отвагу и мужество в бою и является той высшей справедливостью, которая семантически отождествляется с правом. Более того, Тюр не требует и не нуждается в человеческих жертвах, удовлетворяясь жертвами в виде животных. «Убийство за убийство» не прельщает этого военного бога ${ }^{38}$. «Действительно, - сообщает Ж. Дюмезиль, - Tiwaz как будто был покровителем особой формы или некоего субститута права, права не абсолютного, но достигаемого или поддерживаемого средствами, часть из которых, по нашим понятиям, является юридическими, в то время как другие держатся на силе, престиже или запугивании» ${ }^{39}$.

Право и сила (в основном военная) проникают друг в друга и предопределяют формирование особого правового мировоззрения древнего германца, в котором битва воспринимается как суд, а суд как противостояние двух противников ${ }^{40}$. Помимо всего прочего, в древнегерманском обществе право и война просто отождествляются. Доминик Бартелеми в своем эссе также отмечает, что одни и те же люди, как одни и те же институты использовались одновременно для войны и для суда. Армия и народное собрание, осуществляющее функции правосудия, являлись «одними и теми же отростками социальной жизни» древних германцев, так как не было от-

\footnotetext{
${ }^{37}$ См.: Древняя Русь в свете зарубежных источников: Учебное пособие для студентов вузов. М., 1999. С. 413.

${ }^{38}$ См.: Дюмезиль Ж. Верховные боги индоевропейцев. М., 1986. C. 146.

${ }^{39}$ Там же. С. 146 - 147.

40 Там же. С. 147.
} 


\section{Политика и общество 5 (113) • 2014}

дельно ни профессиональных воинов, ни профессиональных юристов. «Воин - это всегда правитель, и в этом аспекте наглядней всего соединяются война и правосудие, а значит, сила и право» ${ }^{41}$. На эту же особенность сочетания военной, административной и судебной власти впоследствии у лангобардских герцогов или гастальдов обращает внимание Л.А. Котельникова ${ }^{42}$.

Мифопоэтическая традиция у древних германцев изначально получает свое отражение исключительно в форме песнопений, затем появляются магические формулы и заклинания, загадки и сказания. Особый интерес представляет так называемый «бардит» - специфический напев без слов, представлявший собой воинственный гул для устрашения врагов ${ }^{43}$. Согласно исследованиям Ф.И. Буслаева, любой народ в самую раннюю эпоху развития уже имеет главные нравственные основы своей национальности в языке и мифологии. Причем эти основы очень тесно и напрямую связаны с поэзией и правом, нравом и обычаями и носят поучительный и религиозный характер. «Все эти национальные основы, - пишет исследователь, - уже глубоко вошли в его нравственное бытие, как самая жизнь, пережитая им в течение многих доисторических веков, как прошедшее, на котором твердо покоится настоящий порядок вещей и все будущее развитие жизни» ${ }^{44}$.

Как правильно замечает В. Лафитский, жизнь права проявляется в образах, которые создаются и живут, в сознании их создающих. Эти правовые образы насыщены красками и звуками, предопределенными не только общественной средой, но и индивидуальными особенностями личного восприятия каждого ${ }^{45}$. Тексты народной устно-поэтической традиции у всех народов очень сходны с юридическими текстами. Элементами такого сходства являются параллельные конструкции, повторы,

${ }^{41}$ Бартелеми Д. Рыцарство: От древней Германии до Франции XII в. СПб., 2012. С. 30.

42 Котельникова Л.А. Феодализм и город в Италии в VIII - XV веках. По материалам центральных и северных областей. М., 1987. С. 26.

43 См.: Введение в германскую филологию: Учебник для филологических факультетов. С. 13.

${ }^{44}$ Буслаев Ф. Исторические очерки русской народной словесности и искусства. Т. 1. СПб., 1861. С. 1.

45 Лафитский В.И. Сравнительное правоведение в образах права. Т. 1. М., 2010. С. 10. фольклорные формулы, рифмообразные элементы и др. Именно эти факторы, по мнению В.В. Иванова и В.Н. Топорова, свидетельствуют о единстве истоков текстов фольклорных и текстов юридических ${ }^{46}$.

В древнейшую эпоху именно поэзия выражала не только миф и обряд, но и судебный порядок ${ }^{47}$. Так, например, в Песне о Велюнде из Старшей Эдды Велюнд просит Нидуда поклясться ему «крепкой клятвой» в том, что не убивал он его жены. Такая клятва, очевидно, как часть процедуры дознания могла использоваться и в судебном процессе. Об этом, в частности, свидетельствует символический характер предметов, на которых осуществляется клятва. Это и борт ладьи, и хребет коня, и край щита, и сталь меча - то есть те предметы, которые составляли, буквально, все для воина-норманна ${ }^{48}$.

Согласно данным К. Лампрехта, в доисторический период у древних германцев само судопроизводство было ничем иным как символом борьбы оружием закона, вместо оружия войны. Одним из самых ярких уголовно-правовых действий-символов являлась процедура изгнания. Так, например, в Наказе Рейнского округа достаточно подробно описывается такая процедура. При обязательном присутствии епископов, старост и судей округа, полномочный посол, имеющий две белые перчатки, становился одной ногой на специальный камень, подбрасывал кверху перчатки и произносил специальную речь: «ныне я стою здесь, отлучаю Гинца или Кунца от отечественного права, объявляю жену его вдовой, а детей его - сиротами, предаю его имущество наследникам, ленное имение его законному господину, шею стране, тело птицам; отныне никто не совершает в отношении него преступления» ${ }^{49}$.

Обладали правовым символизмом и некоторые символы-предметы, используемые в качестве средства осуществления божественного правосудия. Так, Н.П. Павлов-Сильванский приводит пример из древнегерманской мифологии, в котором пер-

\footnotetext{
${ }^{46}$ См.: Иванов В.В., Топоров В.Н. Древнее славянское право: архаичные мифопоэтические основы и источники в свете языка // Формирование раннефеодальных славянских народностей. М., 1981. С. 10.

${ }^{47}$ Буслаев $Ф$. Исторические очерки русской народной словесности и искусства. С. 6.

${ }^{48}$ См.: Старшая Эдда. Древнеисландские песни о богах и героях. М. - Л., 1963. С. 72.

49 Лампрехт К. История германского народа. С. 151 - 152.
} 
чатка, используемая в качестве мерила земли, сыграла роль «наказательного» устройства, оторвав палец межевщику, неправильно измеряющему землю $^{50}$. Меч также являлся символом власти судьи, гарантом неприкосновенности чести девушки (когда клался между мужчиной и девушкой $)^{51}$. П. Колмыков отмечает, что сначала право выражалось исключительно в «поэзии чувственных образов». Затем, по мере развития человеческого общества и формирования языка, язык обогащается словами для понятий отвлеченных, а право «сбрасывает с себя покров чувственных форм» ${ }^{52}$.

Отношение к человеческой жизни как к определенной ценности предопределяется у древних германцев спецификой мифопоэтического восприятия картины мира. Так, считалось необходимым и предписанным судьбой приносить, например, в жертву богам пленных ${ }^{53}$. Описывая обряд жертвоприношения у древнегерманского племени кимвров, древнегреческий историк Страбон отмечает, что жрицыпрорицательницы этого племени собственноручно перерезали горло пленникам, а затем по крови или внутренностям жертвы гадали об исходе битвы ${ }^{54}$.

Хотя, анализируя данные исторические сведения, необходимо соблюдать известную историческую осторожность, так как «География» Страбона это, в первую очередь, «факт литературы», обладающий соответствующей спецификой ${ }^{55}$. Проводя аналогию между мифологией древних германцев и северных скандинавских племен, Р. Элизе пишет, что и у них пленники постоянно приносились в жертву - их бросали в колючие кустарни-

${ }^{50}$ Павлов-Сильванский Н.П. Символизм в древнем русском праве // Журнал министерства народного просвещения. 1905. июнь (часть CCCLIX). C. 355.

51 Там же. С. 359.

52 Колмыков П. О символизме права вообще и русского в особенности . СПб., 1839. С. 18.

${ }^{53}$ Нужно отметить, что у древних германцев пленный (чужак) априори воспринимался как преступник (См.: Бернер А.Ф. Учебник уголовного права: Часть общая. Части общая и особенная: С примечаниями, приложениями и дополнениями по истории русского права и законодательству положительному. Т. 1; Прим.: Неклюдов Н. СПб., 1865. С. 115).

${ }^{54}$ Страбон География. Л., 1964. С. 269.

${ }_{55}$ См.: Грацианская Л.И. Страбон и риторика // Восточная Европа в древности и средневековье. Проблемы источниковедения. Чтения памяти члена-корреспондента АН СССР В.Т. Пашуто. Москва, 18 - 20 апреля 1990 г. М., 1990. С. 39. ки, заживо сдирали кожу, прокалывали кинжалом, а призываемые волхвы чертили на их трупах руны и предсказывали будущее ${ }^{56}$. Согласно точке зрения Б.С. Шалютина, подобного рода жестокое отношение к пленным, как к чужим, не является чем-то из ряда вон выходящим. Именно так называемой «культурной нормой» были усилены естественные механизмы вражды, отношение к чужаку стремительно дегуманизировалось, зачастую, вследствие «псевдовидообразования», когда свой воспринимался как человек исключительный, а чужой - как «ненастоящий» человек ${ }^{57}$.

Понятие судьбы у древнего германца начала меровингской эпохи глубоко индивидуализировано и уже отличается от представления о судьбе «растворенной» личности первобытнообщинного рода. Основу сущностного понимания судьбы составляют две оппозиции - «удача» и «неудача», которые, соответственно, сопутствуют или не сопутствуют в жизни тому или иному человеку. А.Я. Гуревич отмечает, что схватка или состязание между людьми истолковываются именно как сопоставление этих двух категорий ${ }^{58}$. Кроме того, судьба у древних германцев хоть и отождествляется с совершающимся и происходящим, в конечном итоге проецируется на временную ось, конституирует время, заполняет «пустую» временную длительность конкретными событиями человеческой жизни ${ }^{59}$.

Смерть подчинена идее неумолимой судьбы и у древних скандинавов, в миропонимании которых «удача» также противопоставляется «злой воле», способной банальные преступные действия людей превратить в неумолимый рок судьбы. И особенно такое оправдание было свойственно по отношению к представителям княжеских родов и знати ${ }^{60}$. «В представлениях скандинавов о судьбе, удаче или неудаче, - сообщает А.Я. Гуревич, - выража-

56 Элизе Р. Человек и земля. Т. 3: Древняя и новая история. СПб., 1907. С. 317.

${ }^{57}$ Шалютин Б.С. Правогенез как фактор становления общества и человека. С. 15.

58 Гуревич А.Я. Диалектика судьбы у германцев и древних скандинавов // Мифологема женщины-судьбы у древних кельтов и германцев. М., 2005. С. 17.

${ }^{59}$ См.: Топорова T.B. Семантическая структура древнегерманской модели мира. М., 1994. С. 75.

${ }^{60}$ См.: Гуревич А.Я. Диалектика судьбы у германцев и древних скандинавов. С. 15 - 16 . 


\section{Политика и общество 5 (113) • 2014}

ется их отношение к человеческой личности. Человек принадлежит к роду, семье, к органическому коллективу и, безусловно, подчинен тем моральным нормам, которые приняты в обществе. Но при этом он отнюдь не растворяется в группе, и его социальная роль ни в коей мере не сводится к безличному осуществлению ее воли. Выполняя нравственные императивы своей социальной группы, индивид самостоятельно изыскивает способы их реализации. Групповой этнос не служит препятствием для личной инициативы» ${ }^{61}$.

Таким образом, древние германцы и скандинавы продолжая существовать внутри социальной группы и не дистанцируясь от нее, тем не менее, вполне были способны принимать самостоятельные решения, соотносясь с законами морали и права, принятыми в данном обществе и отвечая по этим законам. Неспроста человеческим идеалом древних германцев являлся независимый и свободный воин, а идеал общественный основывался на системе взглядов, характеризовавшихся решением возникающих перед обществом задач на базе добровольного и взаимного сотрудничества всех членов общества ${ }^{62}$. Очевидно, не случайно, поэтому появление в мифопоэтической древнегерманской и скандинавской традиции оппозиции «один - много», «один - все». Хотя необходимо отметить, что древнегерманские племена, вступившие в процесс христианизации, именно христианские ценности принимали за высшую ценность, не перестав почитать за «низшую истину» события, трактуемые в мифологии ${ }^{63}$.

Бинарные мифопоэтические оппозиции, о которых мы упомянули выше, отражали реальную ситуацию варварского древнегерманского общества практически во всех сферах человеческой жизнедеятельности, в том числе и в праве. Поведение отдельно взятого индивида всегда достаточно жестко соотносится с системой кар и наград. И у него, практически, нет выбора, кроме как неукоснительного следования давно предписанным образцам должного и выверенного веками морально-правового пути ${ }^{64}$. Правовые императивы древнегерман-

\footnotetext{
${ }^{61}$ Там же. С. 18.

${ }^{62}$ Аннерс Э. История европейского права. М., 1994. С. 134.

${ }^{63}$ См.: Мелетинский Е.М. «Эдда» и ранние формы эпоса. М., 1968. С. 329, 165.

${ }^{64}$ См.: Гуревич А.Я. Категории средневековой культуры. М.,
} 1984. C. 141. ского варварского общества не противопоставляются морали и не сосуществуют с ней параллельно - они, по сути, нравственны и глубоко религиозны. При этом необходимо отметить, что право также характеризуется эстетическими оттенками.

Право древними германцами понимается как всеобщая и необходимая связь людей ${ }^{65}$. Являясь основой человеческого общежития, право рассматривалось как система связей между людьми. На общенародных сходах право могло говориться, присуждаться, права можно было добиваться и вводить в него других людей. Более того, правом охватывалась всякая упорядоченная связь в мире, получающая позитивную моральную оценку ${ }^{66}$. Но правом и правдой можно было не только «наделить» и «соединить» людей, установить какой-либо юридический факт, но и «разделить». А общий анализ семантических мотивировок древнегерманских обозначений юридических понятий свидетельствует о серьезном сходстве или даже отождествлении судьбы и происходящим в реальной действительности, а также права и обычая ${ }^{67}$. Однако право в догосударственном обществе древних германцев, как мы уже отмечали, не было выделено в особую категорию или сферу жизни, оно рассматривалось как «неотъемлемое измерение человеческого сознания» ${ }^{68}$.

«В мифопоэтических традициях, - пишет Т.В. Топорова, - право понимается более широко, нежели соответствующая современная категория: оно включает представления о законе, реализующемся в нормах, которые определяют поведение индивида в коллективе, и о морали, при этом отсутствует противопоставление права как социального института и как воплощения справедливости, правды» ${ }^{69}$. Протоправо и последующее формирующееся право в древнегерманском обществе во многом выступают в качестве своеобразной «меры социального устройства» аналогичной мере и порядку космизированной вселенной. Вследствие это-

\footnotetext{
${ }^{65}$ Там же. С. 142.

${ }^{66}$ Там же. С. $142-143$.

${ }^{67}$ См.: Топорова T.B. Семантическая структура древнегерманской модели мира. С. 88 - 97.

${ }^{68}$ См.: Гуревич А.Я. Категории средневековой культуры. C. 144 .

${ }^{69}$ Топорова Т.В. Семантическая структура древнегерманской модели мира. С. 87.
} 
го право понимается, а точнее, отождествляется с начальным, исходным пунктом развития мира $^{70}$. Так же как и судьба, право у древних германцев соотносимо с пространственно-временным комплексом. Престиж права, его авторитет, древность и исконность проецируются во времени (сход на судебное заседание) и в пространстве (место судебного производства), приобретая, таким образом, культовое значение ${ }^{71}$.

Но так было далеко не у всех древнегерманских племен. Те племена, которые относились к северной ветви, в минимальной степени были затронуты не только юридической романизацией, но и христианизацией как таковой. Согласно точке зрения Г.В. Мальцева, своеобразие северогерманского права выражалось в «изначально слабом и постоянно снижающимся влиянием религиозной мифологии и религии на нравственную и правовую жизнь» ${ }^{72}$.

В целом христианизация варварского права несла с собой серьезнейшие перемены в миропонимание древнего германца. Мораль продолжала оставаться областью внутренней жизни, подконтрольной ему самому, а вот право вышло за пределы человеческого волеизъявления и превратилось в «сверхиндивидуальную силу», повелевающую им самим $^{73}$. Номократическая средневековая концепция, восходящая к Библии, провозглашала тезис о всеобщем господстве закона, установленного Богом $^{74}$. «Поскольку источником права считается бог, - пишет А.Я. Гуревич, - то отсюда явствовало, что право не может быть несправедливым или дурным, оно - добро, благо по самой своей сути. Право и справедливость - синонимы. Злым, дурным может быть лишь ущемление права, его нарушение или забвение» ${ }^{75}$. В конечном итоге, считает М. Блок, общество церковников выработало для себя собственное право, которое стало абсолютно обособленным в силу его латинизации и преподавания исключительно в церковных школах ${ }^{76}$.

\footnotetext{
${ }^{70}$ Там же. С. 87.

${ }^{71}$ Там же. С. 88.

${ }_{72}$ Мальиев Г.В. Культурные традиции права: монография. M., 2013. С. $151-152$.

${ }^{73}$ См.: Гуревич А.Я. Категории средневековой культуры. С. 146.

${ }^{74}$ Там же. С. 147.

75 Там же. С. 149 - 150.

${ }^{76}$ Блок М. Феодальное общество. М., 2003. С. 114.
}

В более утилитарном смысле, в частности, в области уголовного права христианизация предлагала древнегерманскому образу мыслей совершенно иной взгляд, например, на преступление и его свойства. И если древнегерманская община (мир) в большей степени обращает внимание на внешнюю сторону преступления, то христианство, наоборот, во главу угла ставит внутренние свойства преступлений и наказаний ${ }^{77}$.

Именно христианизация, во многом, обусловила процесс индивидуализации личности из недр первобытного рода, наделения ее душой, как основой человеческой индивидуальности. Но христианизация привела не только к уходу от «родовой личности», она способствовала включению человека в иные (феодальные) коллективы и появлению личности нового плана - «сословной личности» ${ }^{78}$. И в этом случае человек продолжает принимать стандарты жизни этой группы, ее ценности и идеалы, формы поведения ${ }^{79}$. В конечном итоге это приводит к формированию устойчивого и специфического отношения человека к человеческой жизни. Человеческая жизнь - ценность, но ее «стоимость» находится в жестких тисках социально-правовой стратификации, предопределяемой неумолимой судьбой.

Очевидно, что процесс превращения древнего германца времен Цезаря и Тацита в homo juridicus имеет свои особенности, среди которых следует отметить следующие. Появление на исторической сцене древних германских племен связано с процессом их переселения, движения, смены «ареала» существования, а значит, неизбежно с военными столкновениями с коренным населением захватываемых земель. Отсюда рождение права силы, формирующего особый образ человека-воина, прошедшего процедуру инициации, свободного юридического субъекта. Пленный враг, чужой, а значит не только враг, но и преступник, достойный самого сурового наказания, за то, что оказал сопротивление. Право силы, право войны санкционируется верховными антропоморфными божествами, а значит близкими

\footnotetext{
${ }_{77}$ См.: Бернер А.Ф. Учебник уголовного права: Часть общая. Части общая и особенная: С примечаниями, приложениями и дополнениями по истории русского права и законодательству положительному. Т. 1. С. 111.

${ }^{78}$ См.: Гуревич А.Я. Категории средневековой культуры. C. $269-270$.

79 Там же. С. 271.
} 


\section{Политика и общество 5 (113) • 2014}

и понятными, достойными подражания или порицания. Враг-герой иногда достоин уважения. Свобода юридического субъекта выражается в возможности всеобъемлющего участия в жизни общества, в решении вопросов войны и мира, правосудия. И хотя правовая сторона жизни общества не выделяется в особую сферу, она инвариантна, и, вместе с тем, проста и понятна каждому. Правовой обычай в основном сформирован социально-политическим устройством древнегерманского общества, но также неразрывно связан с религией, которая также подвержена видовой трансформации. Во многом, характер правогенеза у древних германцев носил уголовно-правовой оттенок, так как неразрывно был связан с решением именно тех важнейших вопросов (жизни, смерти, чести, родового кровомщения), которые изначально во всем мире относились именно к данной сфере правового регулирования.

\section{Библиография:}

1. Адам Бременский, Гельмольд из Босау, Арнольд Любекский Сла-вянские хроники / Пер. с лат. И.В. Дьяконова, Л.В Разумовский, редактор-составитель И.А. Настенко. - М.: «СПСЛ», «Русская панорама», 2011. - 584 с.

2. Аннерс Э. История европейского права / Э. Аннерс. - М.: Наука, 1994. - 395 с.

3. Бартелеми Д. Рыцарство: От древней Германии до Франции ХІІ в. Пер. с франц. М.Ю. Некрасова / Д. Бартелеми. - СПб.: ЕВРАЗИЯ, 2012. -584 c.

4. Бернер А. Ф. Учебник уголовного права: Часть общая. Части общая и особенная: С примечаниями, приложениями и дополнениями по истории русского права и законодательству положительному. Т. 1; Прим.: Неклюдов Н. / А.Ф. Бернер. - СПб.: Тип. Н. Тиблена и комп., 1865. - 447 с.

5. Блок М. Феодальное общество: Пер. с франц. М.Ю. Кожевниковой / М. Блок. - М.: Изд-во им. Сабашниковых, 2003. - 503 с.

6. Буслаев Ф. Исторические очерки русской народной словесности и искусства. Т. 1 / Ф. Буслаев. - СПб.: В тип. товарищества «Общественная польза», 1861. - 643 с.

7. Введение в германскую филологию: Учебник для филологических факультетов / М.Г. Арсеньева и др. - М.: ГИС, 2000. - 314 с.
8. Грацианская Л.И. Страбон и риторика // Восточная Европа в древности и средневековье. Проблемы источниковедения. Чтения памяти члена-корреспондента АН СССР В.Т. Пашуто. Москва, 18 - 20 апреля 1990 г. - М.: Ин-т истории АН СССР, 1990. С. 39 - 40.

9. Грацианский Н.П. Из социально-экономической истории западно-европейского средневековья. Сборник статей / Н.П. Грацианский. М.: Изд-во Академии наук СССР, 1960. - 407 с.

10. Гуревич А.Я. Диалектика судьбы у германцев и древних скандинавов // Мифологема женщинысудьбы у древних кельтов и германцев. - М.: Индрик, 2005. С. $12-22$.

11. Гуревич А.Я. Категории средневековой культуры / А.Я. Гуревич. - М.: Искусство, 1984. $318 \mathrm{c}$.

12. Данилова Г.М. Возникновение феодальных отношений у франков VI - VII вв. / Г.М. Данилова. - Петрозаводск: Гос. изд-во Карельской АССР, 1969. - 260 с.

13. Дельбрюк Г. История военного искусства в рамках политической истории. Т. 2: Германцы / Г. Дельбрюк. - СПб.: «Наука», «Ювента», 1999. $-352 \mathrm{c}$.

14. Древняя Русь в свете зарубежных источников: Учебное пособие для студентов вузов: Под ред. Е.А. Мельниковой. - М.: Изд. корпорация «Логос», 1999. - 608 с.

15. Дюмезиль Ж. Верховные боги индоевропейцев. Пер. с франц. Т.В. Цивьян / Ж. Дюмезиль. - М.: Главное издательство восточной литературы изд-ва «Наука», 1986. - 234 с.

16. Записки Юлия Цезаря и его продолжателей о галльской войне, о гражданской войне, об александрийской войне, об африканской войне: Пер. и коммент. М.М. Покровского. - М. - Л.: Изд-во Акад. наук СССР, 1948. - 559 с.

17. Иванов В.В., Топоров В.Н. Древнее славянское право: архаичные мифопоэтические основы и источники в свете языка // Формирование раннефеодальных славянских народностей. - М.: Наука, 1981. - С. $10-31$.

18. Иордан О происхождении и деяниях гетов. Вступ. Статья, перевод, коммент. Е.Ч. Скржинской / Иордан. - М.: Изд-во восточной литературы, 1960. -435 с.

19. История Германии: учебное пособие. В 3 т. / Под общ. ред. Б. Бонвеча, Ю.В. Галактионова. 
- М.: КДУ, 2008. Т. 1: С древнейших времен до создания Германской империи / Отв. ред. С.А. Васютин, Е.П. Глушанин. - 544 с.

20. История средних веков: Под ред. А.Д. Удальцова, Е.А. Косминского, О.Л. Ванштейна. Т. 1. М.: ОГИЗ, 1941. - 504 с.

21. Ковалев И.В. Очерки истории Германии с древнейших времен до 1918 г. / И.В. Ковалев, М.А. Коган, И.М. Кривоуз, Р.С. Мнухина. М.: Гос. уч. - пед. изд-во Мин. Прос. РСФСР, 1959. -357 c.

22. Колмыков П. О символизме права вообще и русского в особенности / П. Колмыков. - СПб.: В тип. Карла Крайя, 1839.

23. Косвен М.О. Семейная община и патронимия / М.О. Косвен. - М.: Изд-во Акад. наук СССР, 1963. -218 c.

24. Котельникова Л.А. Феодализм и город в Италии в VIII - XV веках. По материалам центральных и северных областей: Отв. ред. В.И. Рутенбург / Л.А. Котельникова. -М.: Наука, 1987. - 253 c.

25. Куторга М. Политическое устройство германцев до шестого столетия / М. Куторга. - СПб.: Печатано в тип. Х. Гинце, 1837. - 115 с.

26. Лампрехт К. История германского народа. Т. 1. Пер. с нем. П. Николаева / К. Лампрехт. - М.: Типолитография В. Рихтер, 1894. - 608 с.

27. Лафитский В.И. Сравнительное правоведение в образах права. Т. 1 / В.И. Лафитский. - М.: Статут, 2010. - 429 с.

28. Мальцев Г.В. Культурные традиции права: монография / Г.В. Мальцев. - М.: Норма: ИНФРА-М, 2013. - 608 с.

29. Мелетинский Е.М. «Эдда» и ранние формы эпоса / Е.М. Мелетинский. - М.: Наука, 1968. $-363 \mathrm{c}$.

30. Павлов-Сильванский Н.П. Символизм в древнем русском праве // Журнал министерства народного просвещения. - 1905. - июнь (часть CCCLIX). - C. $339-365$.

31. Петрушевский Д.М. Очерки из истории средневекового общества и государства / Д.М. Петрушевский. - М.: Гос. изд-во, 1922. - 298 с.

32. Сорокина Е.А. Статус семьи у древних германцев (к проблеме семантической реконструкции) // Индоевропейское языкознание и классическая филология. - 2009. - Т. ХІІІ. № 1 . - С. $483-492$.
33. Старшая Эдда. Древнеисландские песни о богах и героях: Пер. А.И. Корсуна; Ред., вступит. статья и коммент. М.И. Стеблин-Каменского. М. - Л.: Изд-во Акад. наук СССР, 1963. - 259 с.

34. Стефанович П.С. Дружинный строй в Древней Руси и у древних германцев: существовала ли клятва верности вождю (правителю)? // Древняя Русь. Вопросы медиевистики. 2008. - № 2 .

35. Страбон География. В 17-ти книгах: Под общ. ред. С.Л. Утченко / Страбон. - Л.: Изд-во «Наука», 1964. - 941 с.

36. Тацит Корнелий Сочинения в 2 т. Т. 1: Анналы. Малые произведения: Изд. подгот. А.С. Бобович, Я.М. Боровский, М.Е. Сергеенко / Корнелий Тацит. - Л.: Изд-во «Наука», 1969. - 443 с.

37. Топорова Т.В. Семантическая структура древнегерманской модели мира / Т.В. Топорова. М.: Радикс, 1994. - 190 с.

38. Турыгин А.А. Формы легитимации королевской власти в средневековой германской истории // Вестник российского государственного гуманитарного университета. - 2010. - № 14. С. $88-96$.

39. Цезарь Гай Юлий Записки о войне с галлами. Книга 1: С введ. и коммент. С.И. Соболевского / Гай Юлий Цезарь. - М.: Изд-во лит. на иностр. языках, 1946. - 191 с.

40. Шалютин Б.С. Правогенез как фактор становления общества и человека // Вопросы философии. - 2011. - № 11. - С. $14-26$.

41. Элизе Р. Человек и земля. Т. 3: Древняя и новая история: Пер. с франц. П.Ю. Шмидта / Р. Элизе. - СПб.: Тип. Акц. Общ. Брокгауз-Ефрон, 1907. $-622 \mathrm{c}$.

42. Г. В. Станкевич Религиозные факторы в политике современных государств // Право и политика. - 2011. - 7. - С. $1096-1100$.

\section{References (transliteration):}

1. Adam Bremenskii, Gel'mol'd iz Bosau, Arnol'd Lyubekskii Sla-vyanskie khroniki / Per. s lat. I.V. D’yakonova, L.V Razumovskii, redaktor-sostavitel' I.A. Nastenko. - M.: «SPSL», «Russkaya panorama», 2011. $-584 \mathrm{~s}$.

2. Anners E. Istoriya evropeiskogo prava/E. Anners. - M.: Nauka, 1994. - 395 s. 


\section{Политика и общество 5 (113) • 2014}

3. Bartelemi D. Rytsarstvo: Ot drevnei Germanii do Frantsii XII v. Per. s frants. M.Yu. Nekrasova / D. Bartelemi. - SPb.: EVRAZIYa, 2012. - 584 s.

4. Berner A. F. Uchebnik ugolovnogo prava: Chast' obshchaya. Chasti obshchaya i osobennaya: S primechaniyami, prilozheniyami i dopolneniyami po istorii russkogo prava i zakonodatel'stvu polozhitel'nomu. T. 1; Prim.: Neklyudov N. / A.F. Berner. - SPb.: Tip. N. Tiblena i komp., 1865. - 447 s.

5. Blok M. Feodal'noe obshchestvo: Per. s frants. M.Yu. Kozhevnikovoi / M. Blok. - M.: Izd-vo im. Sabashnikovykh, 2003. - 503 s.

6. Buslaev F. Istoricheskie ocherki russkoi narodnoi slovesnosti i iskusstva. T. 1 / F. Buslaev. - SPb.: V tip. tovarishchestva «Obshche-stvennaya pol'za», 1861. - 643 s.

7. Gratsianskaya L.I. Strabon i ritorika // Vostochnaya Evropa v drevnosti i srednevekov'e. Problemy istochnikovedeniya. Chteniya pamyati chlena-korrespondenta AN SSSR V.T. Pashuto. Moskva, 18 - 20 aprelya 1990 g. - M.: In-t istorii AN SSSR, 1990. S. $39-40$.

8. Gratsianskii N.P. Iz sotsial'no-ekonomicheskoi istorii zapadno-evropeiskogo srednevekov'ya. Sbornik statei / N.P. Gratsianskii. - M.: Izd-vo Akademii nauk SSSR, 1960. - 407 s.

9. Gurevich A.Ya. Dialektika sud'by u germantsev i drevnikh skandinavov // Mifologema zhenshchinysud'by u drevnikh kel'tov i germantsev. - M.: Indrik, 2005. S. $12-22$.

10. Gurevich A.Ya. Kategorii srednevekovoi kul'tury / A.Ya. Gurevich. - M.: Iskusstvo, 1984. - 318 s.

11. Danilova G.M. Vozniknovenie feodal'nykh otnoshenii u frankov VI - VII vv. / G.M. Danilova. - Petrozavodsk: Gos. izd-vo Karel'skoi ASSR, 1969. $-260 \mathrm{~s}$.

12. Del'bryuk G. Istoriya voennogo iskusstva v ramkakh politicheskoi istorii. T. 2: Germantsy / G. Del'bryuk. - SPb.: «Nauka», «Yuventa», 1999. $352 \mathrm{~s}$.

13. Dyumezil' Zh. Verkhovnye bogi indoevropeitsev. Per. s frants. T.V. Tsiv'yan / Zh. Dyumezil'. - M.: Glavnoe izdatel'stvo vostochnoi literatury izd-va «Nauka», 1986. - 234 s.

14. Zapiski Yuliya Tsezarya i ego prodolzhatelei o gall'skoi voine, o grazhdanskoi voine, ob aleksandriiskoi voine, ob afrikanskoi voine: Per. i komment. M.M. Pokrovskogo. - M. - L.: Izd-vo Akad. nauk SSSR, 1948. - 559 s.
15. Ivanov V.V., Toporov V.N. Drevnee slavyanskoe pravo: arkhaichnye mifopoeticheskie osnovy $\mathrm{i}$ istochniki $\mathrm{v}$ svete yazyka // Formirovanie rannefeodal'nykh slavyanskikh narodnostei. - M.: Nauka, 1981. - S. $10-31$.

16. Iordan $\mathrm{O}$ proiskhozhdenii i deyaniyakh getov. Vstup. Stat'ya, perevod, komment. E.Ch. Skrzhinskoi / Iordan. - M.: Izd-vo vostochnoi literatury, 1960. - $435 \mathrm{~s}$.

17. Kovalev I.V. Ocherki istorii Germanii s drevneishikh vremen do 1918 g. / I.V. Kovalev, M.A. Kogan, I.M. Krivouz, R.S. Mnukhina. - M.: Gos. uch. - ped. izd-vo Min. Pros. RSFSR, 1959. - 357 s.

18. Kolmykov P. O simvolizme prava voobshche i russkogo v osobennosti / P. Kolmykov. - SPb.: V tip. Karla Kraiya, 1839.

19. Kosven M.O. Semeinaya obshchina i patronimiya / M.O. Kosven. - M.: Izd-vo Akad. nauk SSSR, 1963. - $218 \mathrm{~s}$.

20. Kotel'nikova L.A. Feodalizm i gorod v Italii v VIII - XV vekakh. Po materialam tsentral'nykh i severnykh oblastei: Otv. red. V.I. Rutenburg / L.A. Kotel'nikova. -M.: Nauka, 1987. - 253 s.

21. Kutorga M. Politicheskoe ustroistvo germantsev do shestogo stoletiya / M. Kutorga. - SPb.: Pechatano v tip. Kh. Gintse, 1837. - 115 s.

22. Lamprekht K. Istoriya germanskogo naroda. T. 1. Per. s nem. P. Nikolaeva / K. Lamprekht. - M.: Tipolitografiya V. Rikhter, 1894. - 608 s.

23. Lafitskii V.I. Sravnitel'noe pravovedenie v obrazakh prava. T. 1 / V.I. Lafitskii. - M.: Statut, 2010. - $429 \mathrm{~s}$.

24. Mal'tsev G.V. Kul'turnye traditsii prava: monografiya / G.V. Mal'tsev. - M.: Norma: INFRA-M, 2013. $-608 \mathrm{~s}$.

25. Meletinskii E.M. «Edda» i rannie formy eposa / E.M. Meletinskii. - M.: Nauka, 1968. - 363 s.

26. Pavlov-Sil'vanskii N.P. Simvolizm v drevnem russkom prave // Zhurnal ministerstva narodnogo prosveshcheniya. - 1905. - iyun' (chast' CCCLIX). - S. $339-365$.

27. Petrushevskii D.M. Ocherki iz istorii srednevekovogo obshchestva i gosudarstva / D.M. Petrushevskii. - M.: Gos. izd-vo, 1922. - 298 s.

28. Sorokina E.A. Status sem'i u drevnikh germantsev (k probleme semanticheskoi rekonstruktsii) // Indoevropeiskoe yazykoznanie i klassicheskaya filologiya. - 2009. - T. XIII. - № 1. - S. 483 - 492.

29. Starshaya Edda. Drevneislandskie pesni o bogakh i geroyakh: Per. A.I. Korsuna; Red., vstupit. stat'ya 
i komment. M.I. Steblin-Kamenskogo. - M. - L.: Izd-vo Akad. nauk SSSR, 1963. - $259 \mathrm{~s}$.

30. Stefanovich P.S. Druzhinnyi stroi v Drevnei Rusi i u drevnikh germantsev: sushchestvovala li klyatva vernosti vozhdyu (pravitelyu)? // Drevnyaya Rus'. Voprosy medievistiki. - 2008. - № 2.

31. Strabon Geografiya. V 17-ti knigakh: Pod obshch. red. S.L. Utchenko / Strabon. - L.: Izd-vo «Nauka», 1964. $-941 \mathrm{~s}$.

32. Tatsit Kornelii Sochineniya v 2 t. T. 1: Annaly. Malye proizvedeniya: Izd. podgot. A.S. Bobovich, Ya.M. Borovskii, M.E. Sergeenko / Kornelii Tatsit. - L.: Izd-vo «Nauka», 1969. - $443 \mathrm{~s}$.

33. Toporova T.V. Semanticheskaya struktura drevnegermanskoi modeli mira / T.V. Toporova. - M.: Radiks, 1994. - 190 s.
34. Turygin A.A. Formy legitimatsii korolevskoi vlasti v srednevekovoi germanskoi istorii // Vestnik rossiiskogo gosudarstvennogo gumanitarnogo universiteta. - 2010. - № 14. - S. 88 - 96.

35. Tsezar' Gai Yulii Zapiski o voine s gallami. Kniga 1: S vved. i komment. S.I. Sobolevskogo / Gai Yulii Tsezar'. - M.: Izd-vo lit. na inostr. yazykakh, 1946. - $191 \mathrm{~s}$.

36. Shalyutin B.S. Pravogenez kak faktor stanovleniya obshchestva i cheloveka // Voprosy filosofii. 2011. - № 11. - S. 14 - 26.

37. Elize R. Chelovek i zemlya. T. 3: Drevnyaya i novaya istoriya: Per. s frants. P.Yu. Shmidta / R. Elize. $-\mathrm{SPb}$.: Tip. Akts. Obshch. Brokgauz-Efron, 1907. - 622 s.

38. G. V. Stankevich Religioznye faktory v politike sovremennykh gosudarstv // Pravo i politika. 2011. - 7. - C. $1096-1100$. 